\title{
The Context of the Teaching Methods of Full Communicative Competence in English of the 11th Grade Teachers of the Middle Technical - Vocational Institutes in the Province of Cabinda (Angola)
}

\author{
Armando Joao \\ Universidade Onze de Novembro (Angola) \\ Francisco Raso Sanchez \\ Universidad de Granada
}

doi: 10.19044/esj.2017.v13n8p15 URL:http://dx.doi.org/10.19044/esj.2017.v13n8p15

\begin{abstract}
The objective of this article is to analyse the context of teaching methods of English as a foreign language of English teachers of 11th grade of the Middle Technical - Vocational Institutes of Cabinda (Angola). This work consists of understanding why students do not learn full communicative competence in English, the reasons why students study this subject for two years in tenth and eleventh grade at school and three years in seventh to ninth grade but do not speak, do not read and can't even understand a simple request. They finish their studies without acquiring necessary linguistic competence in English. However, it is known that the role of the teacher is to guide the students to build their knowledge to orient their social lives. The results of the research show that teachers mostly use grammar translation methods, and they don't use other pedagogical resources such as publicity posters which would help students to acquire the necessary linguistic communicative competences
\end{abstract}

Keywords: Context, Method of Teaching, Communicative Competence, English Language

\section{Introduction}

The present study is part of a research leading to the degree of Doctor of educational sciences, in which we intend to research the observations made in the province of Cabinda (Angola) regarding the students of the 11th grade in the discipline of English as a Foreign Language of the Middle Technical - Vocational Institutes, which students study for 180 periods for 
two years, in the 10th and 11th grade, in addition to the 270 periods during the 1st Cycle of Teaching, i.e. in the 7th, 8th and 9th grade (Octávio, 2011 ).

We think that the English language is really important because it helps them in the labour market, when they work with expatriates, while researching articles written in English, in trips to countries where English is the official language or even when faced with speakers of other languages (Pym, 2013).

The research in question refers to the context of the teaching methods of full communicative competences in English of the 11th grade teachers of the middle technical - vocational institutes in the province of Cabinda, and whose focus is to analyse this particular framework of the teaching methods of these teachers.

English language is classified as one of the most international languages as it is spoken on all continents and is in almost all fields of knowledge and recreation. It is the language most used by internet users, it is also considered as the language of travel, sports and tourism.

The teaching of English in Angola is considered as a paradox for many teachers and students because the absenteeism rate is very high, which is why teachers face enormous difficulties in carrying out their activities, since their desire to teach is not met by corresponding attitudes in the schools where they are placed (Rodrigues \& Ferrão, 2012).

In contrast to other countries' perspectives, English has become globally acknowledged, as it is used in the commercial, technological, diplomatic fields and widely used in fields of education. It is now common for people, stimulated by employment, business, and cultural needs to seek training in English language centres because of the need to speak English fluently and to communicate with others. For the communication to exist, there must be at least two people present (Rodrigues \& Ferrão, 2012).

Complete communicative competences are built through the students' linguistic environment with respect to the foreign language. Experiments have shown that students develop their competences through the influence of the communicative speaking community, such as teachers, colleagues and films with subtitles. In the opinion of these authors, "in the same way in which one learns the mother tongue, one can learn a second language in bilingual situations" (Munõz, Araújo \& Ceia, 2011: 31).

According to Flores (2009), competence is the psychological configuration that includes several cognitive, motivational, metacognitive components and qualities in a close functional unit, which self-regulates the actual and efficient performance in a specific sphere of activity, considering the socially desired model of performance in a concrete historical context. Competence is a psychological configuration, in which its components are cognitive and affective, the translation of texts, and must, in principle, 
produce information that is new to the language or the culture, so it can't be expected to be natural (Pym, 2013).

Teaching methods start from the deductive and inductive perspective, and consider the managerial, non-managerial and semi-direct nature in the teaching-learning process is highly necessary (Rodrigues \& Ferrão, 2012). The context of the teaching methods underscores the main aspect of this research, due to the problem found in the teaching of English in Cabinda's Technical-Vocational schools. Indeed, in all activities that involve human effort, in order to be carried out, it is important to have a certain method that works as a path and set of guidelines that indicate what to do and how to get to the desired goal. In the process of teaching and learning, teachers are increasingly complaining about student learning, and students complain about how teachers teach (Cardoso, 2013).

In addition to the teaching methodology, teachers use didactics, which is the comprehensive study of the structure of the contents, objectives, methods and non-personal components of the teaching and learning process. The method is understood as the way that the teacher finds to facilitate teaching and student learning, and teaching and learning strategy is the acquisition of an easily transferable manner to proceed, with a view to optimizing results (Perraudeau, 2013: 29).

In this case, in order to teach, the teachers first diagnose the context in which they will work to discover the students' reality and work according to their needs. This diagnosis allows teachers to delineate the method corresponding to the students' characteristics for an effective teaching process.

In carrying out their activities, teachers face two inseparable moments, namely the teaching activities and learning activities, so they must have the experience and knowledge to work based on the evaluation carried out at the beginning of the year (Flores, 2010).

According to Rodrigues \& Ferrão (2012), it is in this way, when teachers develop their work plan, that they define both the pedagogical course and the methods to be applied, as a way of anticipating the activities to be carried out, where the teaching activities focus on the organization, direction and regulation of learning activities.

The teacher in a classroom acts as a driving force in making pedagogical choices, that is, choosing and articulating the methods, strategies and teaching methods that are most appropriate to the teaching process (Rodrigues \& Ferrão, 2012). The methodological strategies refer to the techniques and methods that teachers use to determine a particular lesson. All sciences have ways that they can be taught, considering the characteristics of the discipline and the environment of the school. The teacher should be aware that the purpose of teaching is that students 
consolidate what they have been taught and apply what they have learned in real life. The purpose of teaching English is to develop communicative competences. In this sense, the teachers prepare their discipline according to their students, their motivations and the way they present themselves in the school or in the classroom (Rodrigues \& Ferrão, 2012).

The teacher's role includes motivating the student for the overall exercise, enabling them to carry out verbal, written, reading and listening activities. The centre of activity would not be the teacher or the subject matter, but the active, investigative student. The educator encourages, guides and organizes their learning, adapting himself to the capacities and the individual characteristics of the students (António, 2006). In order to influence students' attitudes towards learning, it is essential to create strategies that are apt for the students' application to the procedure in question.

Individuals or groups that have the power to influence decisionmaking on policies and legislation, create public debates, campaigns, community mobilization, use the media to motivate the target audience to change from negative to positive. In fact, putting the right person in the right place and remunerating them according to the standard of living of that people makes a difference in the professional and social context depending on the context (UNESCO, 2013).

Moreover, students should actively participate in these class activities to produce the knowledge or skills they wish to acquire to use in society or future employment. Many students leave the classroom just as they came in and without any type of knowledge, even though they recognise that it helps them to become creative and critical citizens: "...the participation of the students in the classroom increases the interest and the dialogue between the teacher and the students and it is a motivating strategy that gives more meaning to the contents" (Estanqueiro, 2010: 39).

\section{Objectives}

- $\quad$ To analyse the context of the teaching methods of the English as a foreign language of the teachers of the 11th grade of the Middle Technical and Vocational Institutes of the Cabinda Province.

- $\quad$ To identify the 11th grade teachers' teaching methods of English as a foreign language of the Middle Technical and Vocational Institutes of the Cabinda Province.

- $\quad$ To determine the teachers' training profile.

- $\quad$ To check the printed and audio - visual teaching resources available in these schools. 
- To understand the motivation of the students and teachers of the Cabinda Middle Technical and Vocational Institutes with regards to the teaching and learning of the English as a foreign language.

\section{Method}

To achieve the goals, according to the planned research, noting the problem experienced in the five Middle Technical and Vocational institutes in the province of Cabinda, the research, as a human activity, is oriented to the understanding, explanation and transformation of social reality through a systematic inquiry plan, so here’s its raison d’être (Molina, 2015; Sánchez, 2007).

\section{Contextualization}

The context of this research was the province of Cabinda, Angola, located in the subequatorial and tropical zone of the southern hemisphere, in southwest Africa. It borders the Democratic Republic of Congo to the north, Zambia to the east, the Republic of Namibia to the south, and West Angola is situated along the Atlantic Ocean. Cabinda consists of four counties and eight municipalities, namely: the counties of Cabinda, Cacongo, Buco-Zau and Belize. Its surface is approximately $7,270 \mathrm{~km}^{2}$ and its population is 716,070 inhabitants.

It's one of the richest regions of Africa, oil is its main wealth, in addition to petroleum, it still possesses uranium, gold, diamond, phosphate, manganese, iron and diamonds. In terms of agriculture, the province produces coffee, cocoa, bananas, papayas, manioc, citrus, beans, sweet potatoes, macoco potatoes and other agricultural products.

Another characteristic is that Cabinda is the northernmost province of Angola, located between the 4th and 25th parallels of latitude in the southern hemisphere and between the meridians 12 and 13 east longitude; it is located on the west coast of Africa, limited to North, Northeast and Northwest by the Republic of Congo, the East, Northeast and South by the Democratic Republic of Congo and the West by the Atlantic Ocean. It is separated from the rest of the country by a band of less than $50 \mathrm{~km}$. wide by the river Zaire, which is part of the kingdom of Congo.

\section{Descriptive Sample Characteristics}

The sample characteristics of English teachers from the Middle Technical and Vocational institutes in the province of Cabinda participating in this study, which is a total of 35. The table summarizes them with the descriptive statistics of the sample: gender, training courses, academic level, length of service as an English teacher and age (Bisquerra, 2014; Peró, 2012; 
Rodríguez \& Valldeoriola, 2009). The sample is also composed of 350 students.

Table 1: Descriptive Statistics Summary of the Sample of Teachers

\begin{tabular}{|c|c|c|c|c|c|}
\hline & \multicolumn{2}{|c|}{$\mathbf{N}^{\mathbf{0}}$} & \multirow{2}{*}{ Mean } & \multirow{2}{*}{ Mode } & \multirow{2}{*}{$\begin{array}{l}\text { Standard } \\
\text { deviation }\end{array}$} \\
\hline & Valid & Missing & & & \\
\hline GENDER & 35 & 0 & 1,09 & 1 & ,284 \\
\hline TRAINING COURSES & 35 & 0 & 2,26 & 1 & 1,291 \\
\hline ACADEMIC LEVEL & 35 & 0 & 1,57 & 1 & ,739 \\
\hline AGE & 35 & 0 & 1,69 & 1 & ,796 \\
\hline LENGTH OF SERVICE AS TEACHER & 35 & 0 & 1,69 & 1 & ,832 \\
\hline
\end{tabular}

Table 2: Reliability of Students’ Statistics

\begin{tabular}{|c|c|}
\hline Cronbach's Alpha & Nof elements $^{\circ}$ of \\
\hline 0,735 & 33 \\
\hline
\end{tabular}

Table 3: Reliability of Teachers' Statistics

\begin{tabular}{|c|c|}
\hline Cronbach's Alpha & Nof elements $^{\circ}$ of \\
\hline 0,852 & 37 \\
\hline
\end{tabular}

\section{Data Collection Instruments}

To collect data from this research, two questionnaires were produced, one of which was directed to 350 students of the 11th class of the TechnicalVocational Middle Institutes of the province of Cabinda, to find out which teaching methods were used by English teachers. Also, questionnaires were sent to 35 English teachers, with the purpose of understanding their motivation to English teaching, their academic level, gender, age, teaching practices including copying exercises, the practice of translating texts, oral practice, the practice of language skills, the use of the grammatical translation methods and the use of the direct and situational methods.

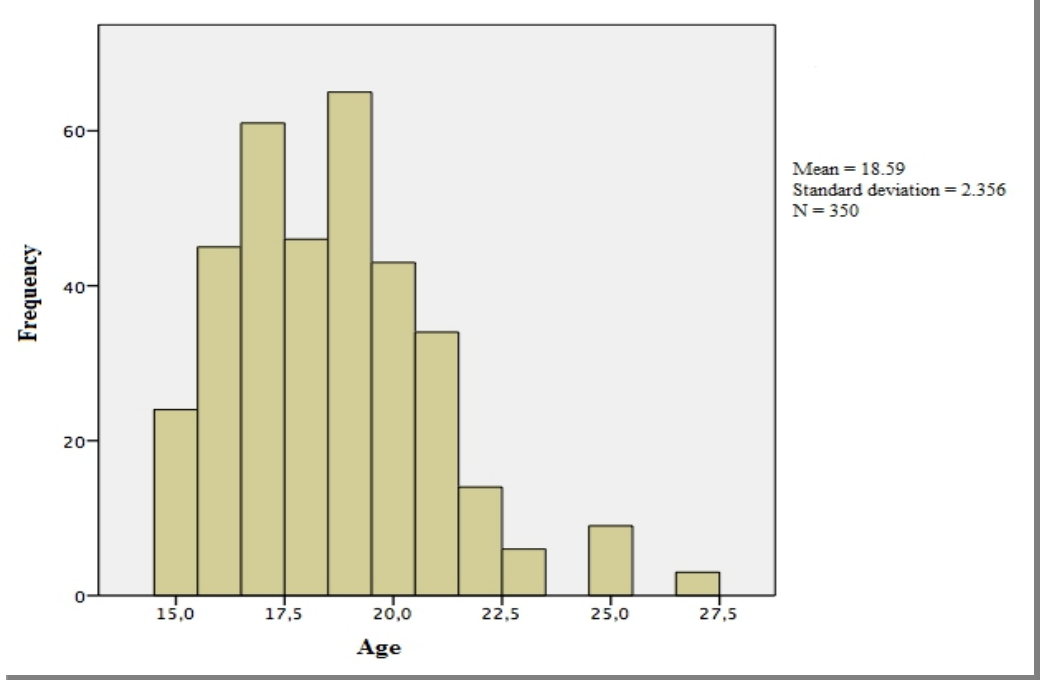

Figure 1: Student Histogram 
Given that taking constant notes is important in learning English, $44.3 \%$ of the student sample considered this important and $36.6 \%$ quite important, which amounts to $80.9 \%$ of the sample. It is important to emphasize that about $20 \%$ of the sample responded negatively to this question. This may be due to the monotonous, routine nature of this activity, which students do not like.

\section{Results}

The translation of texts from English to Portuguese and vice versa, is important for learning English and developing and acquiring full communicative competence. 53.4\% of the students considered this as quite important and a further $41.4 \%$ say it is important. Accordingly, there must be a relationship between theory and practice to mobilize knowledge and acquire skills, because practical activities are absolutely necessary, especially when speaking a language.

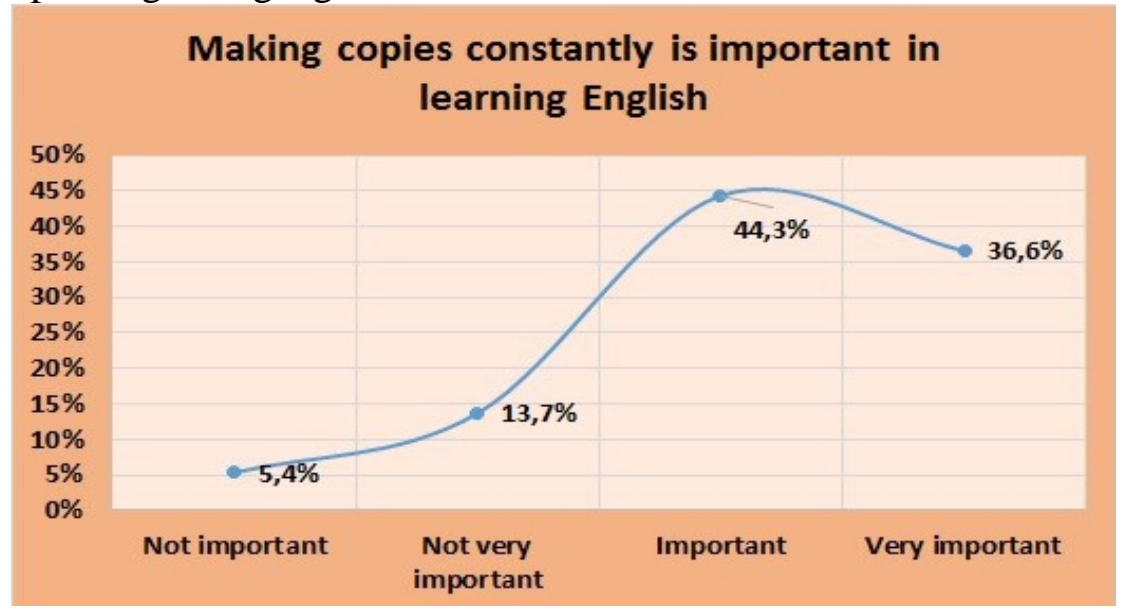

Figure 2: Graph of the Importance of Making Copies While Learning English

In addition to this, we analysed the opinion that the practice of the oral discourse of English in class is important for the improvement of the foreign language. In this case, a trend similar to the previous item follows. On the one hand, $45.7 \%$ of students maintain the opinion that it is quite important and the $45.4 \%$ that is important.

Table 4: The Practice of Translating Texts From English to Portuguese to English are Important in Learning Full Communicative Competences

\begin{tabular}{|c|c|c|c|c|}
\hline & Frequency & $\%$ & Valid Percentage & $\begin{array}{c}\text { Accumulated } \\
\text { Percentage }\end{array}$ \\
\hline NOT IMPORTANT & 12 & 3,4 & 3,4 & 3,4 \\
LESS IMPORTANT & 6 & 1,7 & 1,7 & 5,1 \\
IMPORTANT & 145 & 41,4 & 41,4 & 46,6 \\
VERY IMPORTANT & 187 & 53,4 & 53,4 & 100,0 \\
TOTAL & 350 & 100,0 & 100,0 &
\end{tabular}




\begin{tabular}{|c|c|c|c|c|}
\hline \multicolumn{5}{|c|}{ THE PRACTICE OF SPEAKING ENGLISH IN THE CLASSROOM IS IMPORTANT FOR THE } \\
IMPROVEMENT OF THE ENGLISH LANGUAGE \\
\hline NOT IMPORTANT & 7 & 2,0 & 2,0 & 2,0 \\
LESS IMPORTANT & 24 & 6,9 & 6,9 & 8,9 \\
IMPORTANT & 159 & 45,4 & 45,4 & 54,3 \\
VERY IMPORTANT & 160 & 45,7 & 45,7 & 100,0 \\
TOTAL & 350 & 100,0 & 100,0 & \\
\hline
\end{tabular}

The research covered a total of 35 teachers, in which there is a clear majority of males versus females. $91.4 \%$ of the total of the participants were male teachers, compared to $8.6 \%$ female. The study shows that the teachers' most common educational background was a degree in Foreign Languages (English) with a percentage of 37.1\%, followed by Psychology (28.6\%), African Culture (17.1\%), Pedagogy (11.4\%), and least frequent in this sample is a Management degree (5.7\%). However, most of these teachers were only completing the third year of their English degree, which is consists of 3 years at the Higher Institute of Educational Sciences in the province of Cabinda, so they don't yet have the professional license that qualifies them as trained teachers.

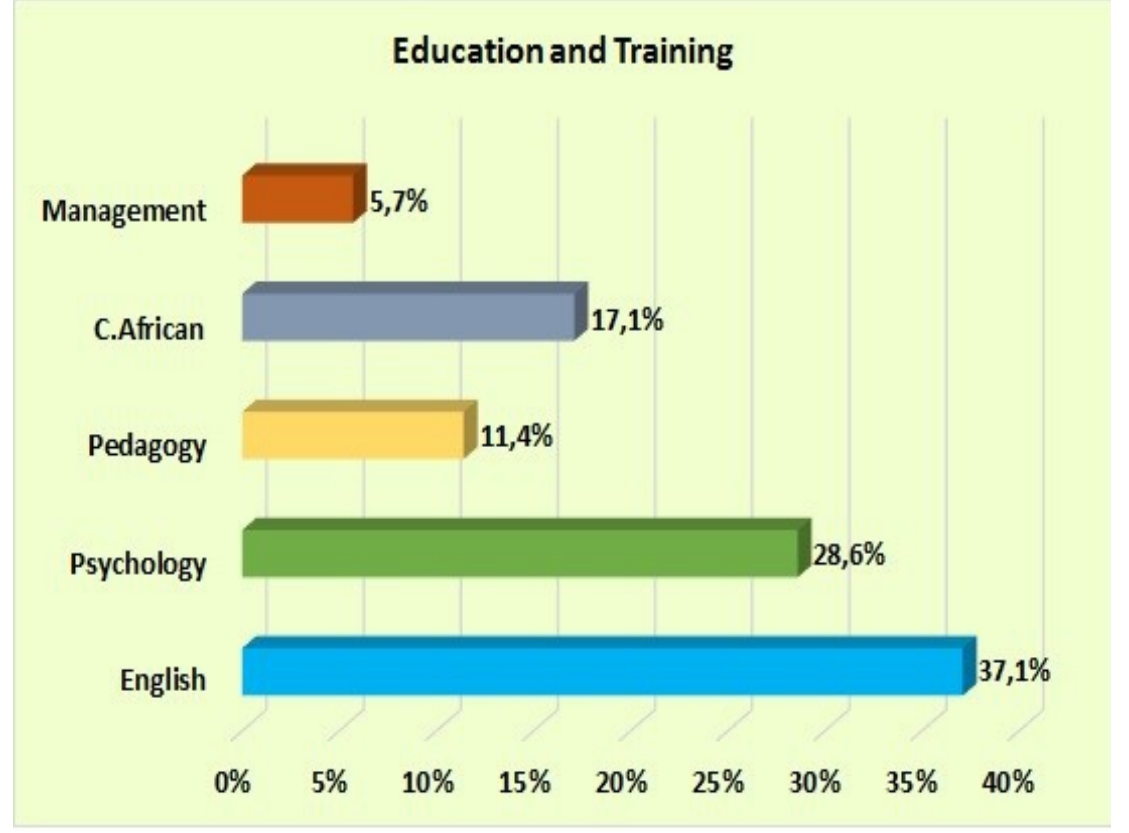

Figure 3: Training Courses

Regarding the academic level of the participants, more than half of the sample has a Bachelor degree, followed by $28.6 \%$ with licentiate degrees and $14.3 \%$ with a Master's. There were no participants with a doctorate. 


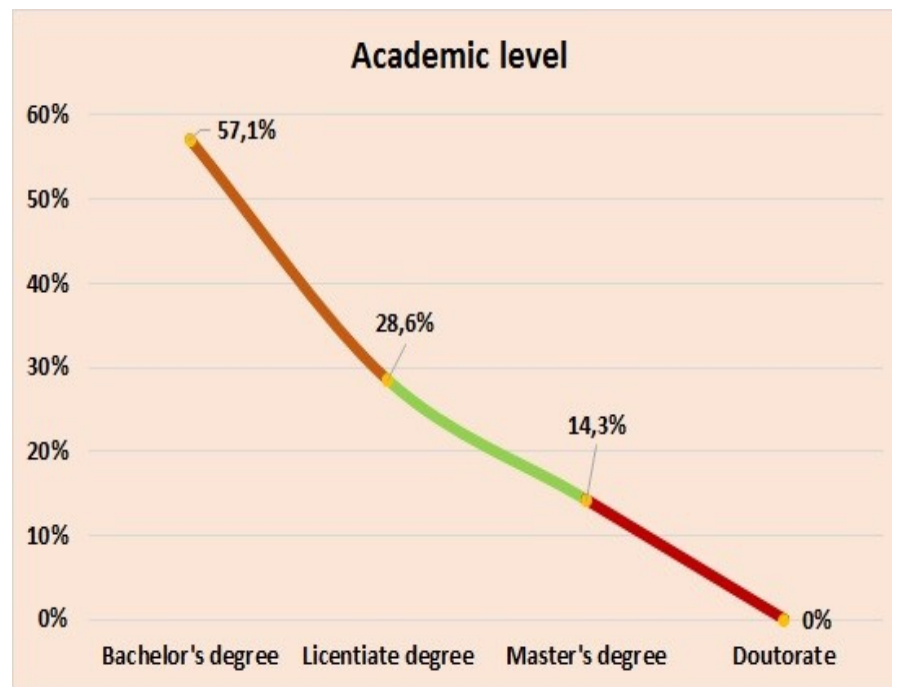

Figure 4: Academic Level

Regarding the question of whether teachers diversify teaching methods in class, such as group work and discussion, $71.4 \%$ of the sample says they agree, together with $17.1 \%$ who completely agree. $11.4 \%$ of teachers say they disagree or completely disagree. If we recall, the data obtained in the instrument applied to the students contradicts these results, since the students affirm that the teachers don't diversify the methodology used in the class.

Also, while the question whether teachers raise the students' awareness for the importance of student learning, $88.5 \%$ of teachers said they either agree $(77.1 \%)$ or completely agree $(11.4 \%) .11 .4 \%$ of teachers disagree, no teacher said they completely disagreed.

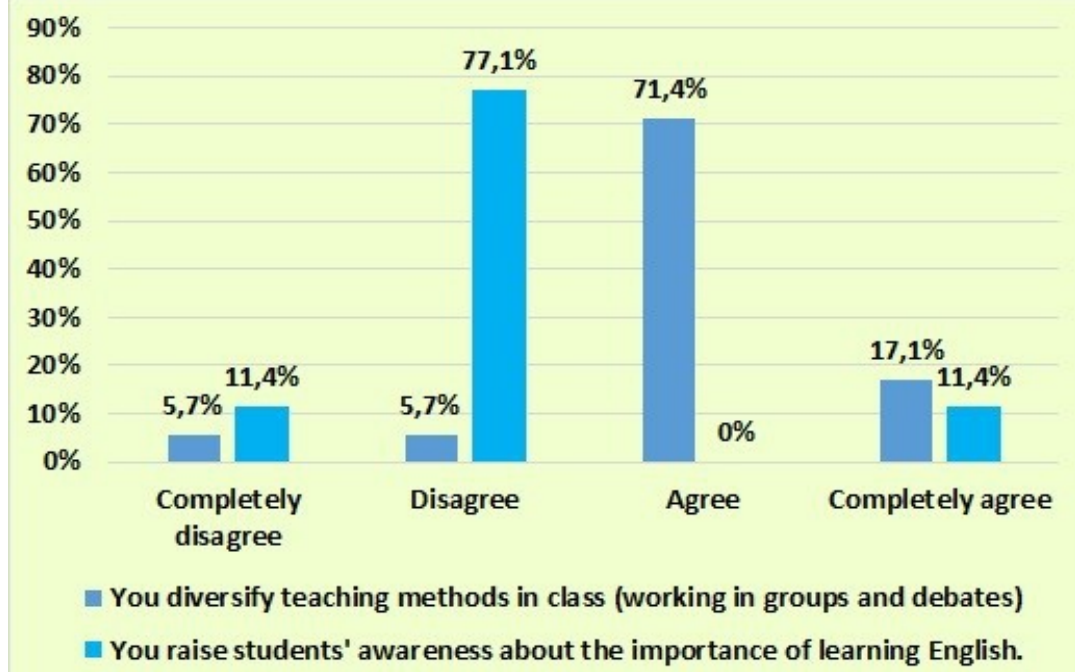

Figure 5: Diversification of Teaching Methods and Awareness for Learning English 
Motivation in professional practice is of great relevance and directly influences the development of teaching work. In this sense, it is shown whether the teacher feels motivated to teach English Language. Most teachers, $45.7 \%$, say they disagree (they are not motivated). $40 \%$ of the teachers agree, and $14.3 \%$ of participants say they completely agree.

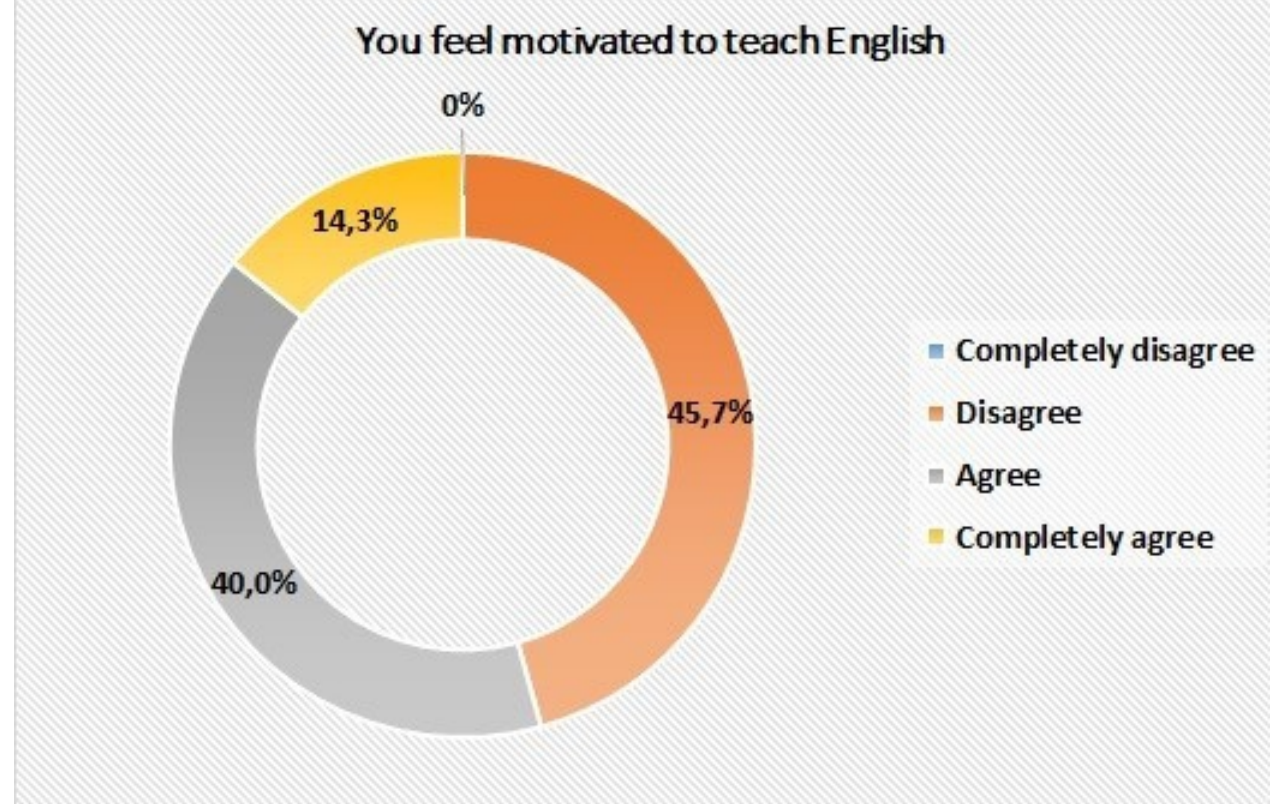

Figure 6: The Motivation to Teach English

The analysis and interpretation of items related to the resources used by the teachers in English Language classes is also very interesting: on the one hand, with respect to the use of music in English teaching, $62.9 \%$ of teachers said that they agree, along with $14.3 \%$ who completely agree. $22.8 \%$ of the sample did not agree, consisting of $17.1 \%$ who disagree and $5.7 \%$ who completely disagree.

When asked whether English teaching in these institutes is carried out through films, the table shows that $45.7 \%$ completely disagree and $17.1 \%$ disagree. This is because there are not enough audio-visual resources in the schools itselves. Just $22.9 \%$ of teachers agree and $14.3 \%$ completely agree.

Finally, when asked whether English language classes are based on songs and interpreting advertising posters, the results show that most teachers don't do this, and either disagree completely (45.7\%) or disagree (34.7\%). Just $20 \%$ of teachers say they agree. 


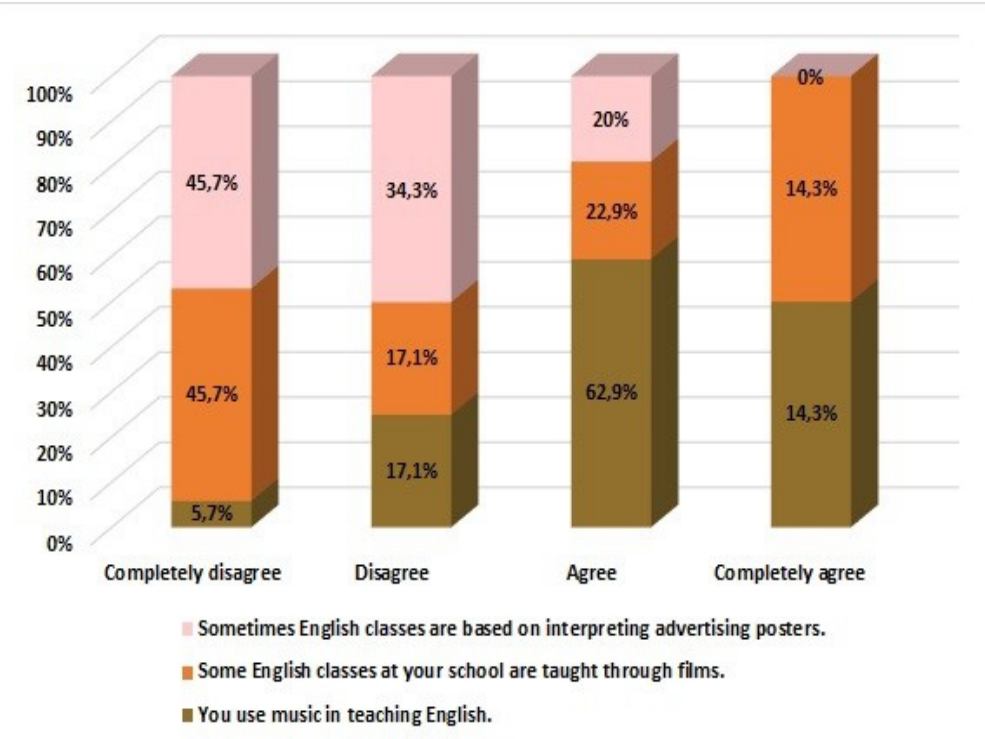

Figure 7: Resources Used in Teaching English

Considering everyday reality in class, we ask whether teachers work harmoniously with all the four language skills in English (listening, speaking, reading and writing). $62.9 \%$ of the participating teachers completely disagree. and $17.1 \%$ disagree with this. We highlight that there $20 \%$ who say they agree. Precisely one of the problems that happens in the teaching of Foreign Languages, especially the English, is the importance, the weight given to some of these abilities rather than others, that is mainly, having good knowledge of grammar, good reading, writing skills, but at the same time deficits in oral skills and auditory comprehension.

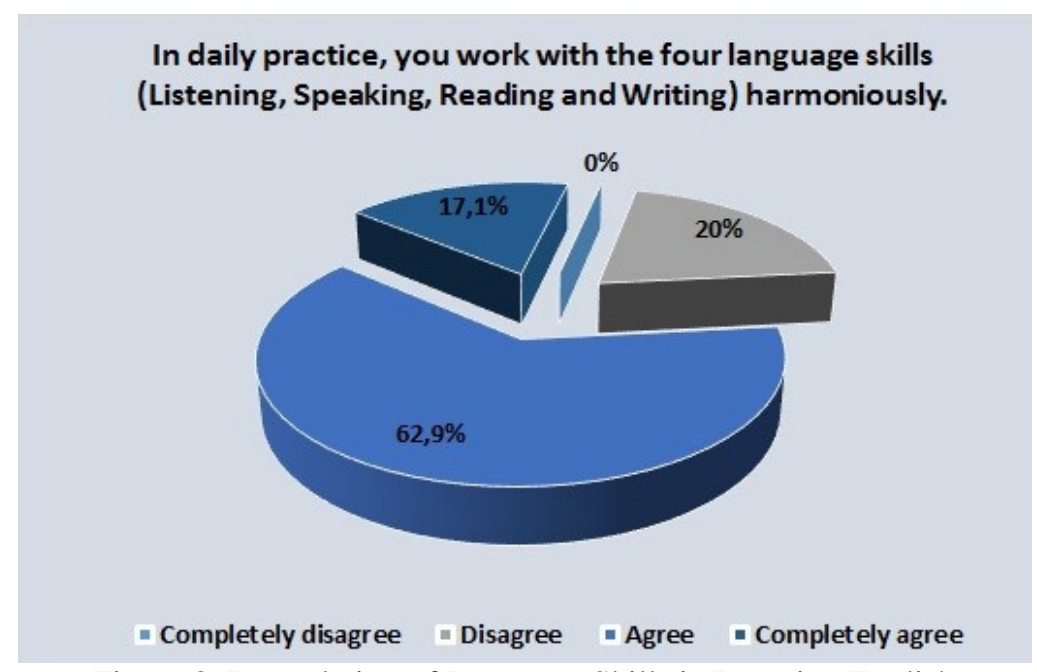

Figure 8: Interrelation of Language Skills in Learning English 
The vast majority use of grammar translation methods in the English class is shown by $74.3 \%$ of teachers, who say they agree, and $8.6 \%$ completely agree, while $17.1 \%$ say they disagree. None of teachers completely disagree. The use of aids has increased considerably in recent years thanks to technological development and their use must consider important aspects such as the interpretation of such translations.

$17.1 \%$ of the participating teachers state that they are in complete disagreement with the use of direct methods in English teaching, together with 34.3\% who do not agree. The sample is divided between the affirmative and negative scales, with $31.4 \%$ agreeing and $17.1 \%$ completely agreeing. While a communicative focus is essential in teaching English, $60 \%$ of teachers completely disagree, while $28.6 \%$ disagree.

We finish with the item that refers to whether the situational method is more useful in the teaching of English; 28.6\% say they completely disagree, and $34.3 \%$ only disagree. A further $37.1 \%$ of the sample is divided between agreeing and completely agreeing with this particular subject.

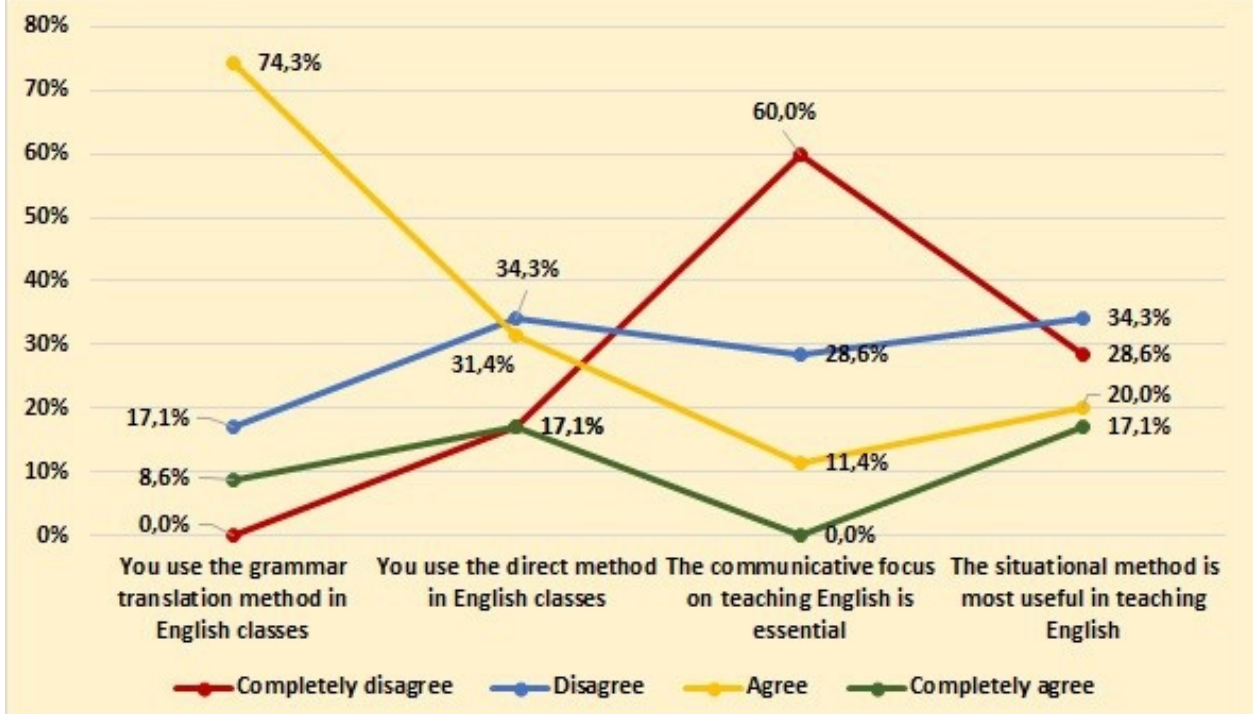

Figure 9: Methods of Teaching English

Regarding satisfaction about teaching English, 11.4\% of this range of teachers completely disagree and $48.6 \%$ disagree; while $28.6 \%$ agree and $11.4 \%$ completely agree. With respect to the satisfaction with the English learning of the students, $20 \%$ completely disagree and $28.6 \%$ disagree; the largest group is $40 \%$ who say they agree and $11.4 \%$ completely agree.

\section{Discussion}

After researching into the context of the teaching methods of full communicative competence of English as a Foreign Language of the teachers 
of the 11th grade of the Middle Technical Vocational Institutes of Cabinda Province, the following was concluded:

- $\quad$ The translation of English to Portuguese and Portuguese to English is very important and helps students to learn, which is shown by $44.3 \%$ of the students saying it was very important and $36.1 \%$ saying it was quite important, totalling $80.4 \%$.

- $\quad$ On the other hand, making copies is an important process that helps in learning to memorize words and familiarize oneself with written English skills, which is demonstrated in the students' responses with $80.9 \%$ who said that writing exercises in or out of the classroom is important. However, $19.1 \%$, the minority of students, claim that this is not important. But the fact is that, to the extent that the students are making copies, they train their memory in assimilating the new vocabulary and this enables the acquisition of integral communicative competence.

- In the question about whether the teacher raises students' awareness about the importance of learning the English language, 88.5\% of the teachers are divided between agreeing with this (77.1\%) and 11.4\% completely agreeing. The teachers' responses reveal that they have raises students' awareness about learning English.

- Also, it was questioned whether teachers feel motivated to teach English; the most significant percentage of teachers is $45.7 \%$, who disagree, while $40 \%$ agreed. As the results show, many teachers do not feel motivated to teach English.

- With regards to the use of songs in English classes and doing exercises to interpret advertising posters; the results show that $45 \%$ of teachers disagree completely, and a further $34.7 \%$ disagree, giving a total of 79.7\% who don't agree with this.

- Teachers work harmoniously the four skills (listening, speaking, reading and writing); $62.9 \%$ of the participants are completely in agreement with this, a further $17.1 \%$ in agreement. Regarding the use of the grammatical translation method in the English class, the clear majority use this method, giving $74.3 \%$ of teachers who affirm that they agree, and $17.1 \%$ disagree, saying that they do not use the grammar translation method.

- A further question was the use of direct methodologies in teaching English, 17.1\% of teachers participating in this research said that they completely agreed, and 34.3\% disagreed. A further $31.4 \%$ disagree completely and $17.1 \%$ disagree that they use these methods. While the communicative approach is essential to teach English, 60\% of teachers completely disagree with this, while $28.6 \%$ agree. 
- When asked whether the Situational Method is more useful in the teaching of English, 28.6\% completely agree, 34.3\% disagree. A further $37,1 \%$ percentage agreed or completely agreed.

- $\quad$ Concerning the question about their satisfaction of teaching English, teachers' answers indicate that $11.4 \%$ strongly disagree and $48,6 \%$ disagree that they are satisfied; while $28.6 \%$ say that they are satisfied or completely satisfied (11.4\%).

- With respect to student learning satisfaction, 20\% completely disagree while $28.6 \%$ disagree; $40 \%$ say they agree with the satisfaction of the students' learning and $11.4 \%$ completely agree.

- Triangulating the results of this research, the study shows that teachers are not satisfied with teaching the English language, due to the lack of teaching materials supporting the didactics of foreign languages, which has been shown in the responses of students and teachers.

- $\quad$ Regarding the context of teaching methods, it was found that most use the method of grammatical translation, where the teacher is limited to writing the subject on the board which the students copy to their notebooks, which is followed by an explanation of the grammatical aspects. This is widespread practice for most teachers.

- $\quad$ Also, the results of the students and teachers reflect the fact that teachers do not create dynamism by using advertising posters, which would make the students curious about dealing with the language in different ways.

- In addition to the study that we have carried out here, we would like to invite the other researchers to continue with this theme, and create strategies capable of affecting the situation noted in this research, as well as other conditions which may be perceived.

\section{References:}

1. António, C.G. (2006). Didáctica do Ensino Superior. São Paulo: Atlas Editora S.A.

2. Bisquerra, R. (2014). Metodología de la Investigación Educativa. Madrid: La Muralla.

3. Cardoso, J.R. (2013). O Professor do Futuro. Lisboa: Guerra e Paz Editora.

4. Estanqueiro, A. (2010). Boas Práticas na Educação: o Papel dos Professores. Lisboa: Editorial Presença.

5. Flores, M.A. (2010). Avaliação de Professores Numa Perspectiva Internacional. Porto: Areal.

6. Flores, M.S. (2009). Aprendizagem e Desenvolvimento Profissional de Professores: Contextos e Perspectivas. Lisboa: Edições Pedago. 
7. Molina, M.D. (2015). Estadística Aplicada a las Ciencias Sociales. Alicante: Universidad de Alicante.

8. Muñoz, C., Araújo, L. \& Ceia, C. (2011). Aprender uma Segunda Língua. Lisboa: Porto Editora.

9. Octávio, M.J. (2011). Currículo do $2^{\circ}$ Ciclo do Ensino Secundário. Luanda: I.N.I.D.E.

10. Peró, M. (2012). Estadística Aplicada a las Ciencias Sociales Mediante R y $R$ - Commander. Madrid: Ibergaceta.

11. Perraudeau, M. (2013). As Estratégias de Aprendizagem: Como Acompanhar os Alunos na Aquisição de Conhecimentos. Lisboa: Instituto Piaget.

12. Pym, A. (2013). Teorias Contemporâneas da Tradução: Uma Abordagem Pedagógica. Lisboa: Fundação Calouste Gulbenkian.

13. Rodrigues, M. \& Ferrão, L.F. (2012). Formação Pedagógica de Formadores. En A.D. Rodrigues (2011). O Paradigma Comunicacional: História e Teorias. Fundação Calouste Gulbenkian: Lisboa.

14. Rodríguez, D. \& Valldeoriola, J. (2009). Metodología de la Investigación. Barcelona: F.U.O.C.

15. Sánchez, J.C. (2007). Estadística Básica Aplicada a la Educación. Madrid: C.C.S.

16. UNESCO. (2013). Projecto de Aceleração do Quadro E.P.T: O Salto Decisivo, Iniciativa a E.P.T. Dakar: Escritório Regional da UNESCO. 